\title{
ANALISIS JUAL BELI KITAB DENGAN SISTEM ONLINE MENURUT PERSPEKTIF FIKIH MUAMALAH
}

\author{
Henny Dwijayani ${ }^{1}$, Slamet Khusaini ${ }^{2}$ \\ Universitas Darul Ulum Jombangl, Institut Agama Islam Darusslam Blokagung \\ Banyuwangi ${ }^{2}$ \\ Email: hennydwija@gmail.com ${ }^{1}$, slamethusaini97@gmail.com²
}

\begin{abstract}
The objectives of this study are: 1) To find out how the contract mechanism is applied in the book buying and selling transaction using the online system, 2) To find out how the muamalah fiqh view of the book buying and selling transactions using the online system. The result of this research is the practice of buying books with an online system by the santri of Darussalam Blokagung Islamic Boarding School in the view of muamalah fiqh is not at all against the law of fiqh, because in practice it starts from transactions, contracts, objects of transactions, to the two transactors (al- 'aqidain) did not violate the rules in the muamalah fiqh. This can be seen from the occurrence of the contract, between the buyer and the seller making an agreement in accordance with the provisions of fiqh, then for the perpetrators they are baligh, sensible, have targeted their own assets and there is no element of coercion from any party, the object is in accordance with the law of figh. That is, it is not in the form of an unclean object, has benefits, its shape can be clearly identified and the new is already its own.
\end{abstract}

\section{Keywords: Buy and Sell Book System Online, Muamalah's Perspective}

\begin{abstract}
Abstrak
Tujuan dari penelitian ini adalah: 1) Untuk mengetahui bagaimana mekanisme akad yang diterapkan dalam transaksi jual beli kitab dengan sistem online, 2) Untuk mengetahui bagaimana pandangan fikih muamalah terhadap transaksi jual beli kitab dengan sistem online. Hasil dari penelitian ini adalah praktik pembelian kitab dengan sistem online yang dilakukan santri Pondok Pesantren Darussalam Blokagung dalam pandangan fikih muamalah sama sekali tidak bertentangan dengan hukum fikih, karena dalam praktiknya mulai dari transaksi, akad, objek transaksi, sampai kedua pelaku transaksi (al-'aqidain) sama sekali tidak melanggar aturan yang ada dalam fikih muamalah. Hal ini dapat dilihat mulai dari terjadinya akad, antara pembeli dan penjual melakukan perjanjian dengan sesuai ketentuan fikih, kemudian untuk para pelaku mereka sudah baligh, berakal, mentasarufkan hartanya sendiri dan tidak ada unsur paksaan dari pihak manapun, objeknya pun sudah sesuai dengan aturan hukum fikih yaitu bukan berupa benda yang najis, memiliki manfaat, bentuknya bisa diketahui secara jelas dan barangnya pun sudah miliknya sendiri.
\end{abstract}

Kata Kunci: Sistem Jual Beli Buku Online, Perspektif Fikih Muamalah 


\section{A. PENDAHULUAN}

Hal yang membedakan bisnis online dengan bisnis offline yaitu proses transaksi (akad) dan media utama dalam proses tersebut. Akad merupakan unsur penting dalam suatu bisnis. Secara umum, bisnis dalam Islam menjelaskan adanya transaksi yang bersifat fisik, dengan menghadirkan benda tersebut ketika transaksi, atau tanpa menghadirkan benda yang dipesan, tetapi dengan ketentuan harus dinyatakan sifat benda secara konkret, baik diserahkan langsung atau diserahkan kemudian sampai batas waktu tertentu, seperti dalam transaksi as-salam dan transaksi al-istishna. Transaksi as-salam merupakan bentuk transaksi dengan sistem pembayaran secara tunai/disegerakan tetapi penyerahan barang ditangguhkan. Sedang transaksi al-istishna merupakan bentuk transaksi dengan sistem pembayaran secara disegerakan atau secara ditangguhkan sesuai kesepakatan dan penyerahan barang yang ditangguhkan. (Nur Fitria, Tira. 2017:56).

Namun madzhab Asy-Syafi'i membolehkan jual beli tersebut dengan syarat barang telah disaksikan terlebih dahulu. Ataupun hanya memperjual belikan barang yang diketahui ciri-ciri dan sifatnya dan barang ada dalam jaminan penjual. Jual beli ini diperbolehkan selama barang yang diperjual belikan sesuai dengan ciriciri yang telah ditentukan. Atau telah diketahui jenis dan sifat dan barang yang akan dibelinya. Dengan kemajuan informasi teknologi spesifikasi barang bisa dilihat terlebih dahulu baik secara gambar dan video. Jika barang tidak sesuai dengan ciri-ciri yang telah disepakati, pembeli boleh melakukan khiyar. Disyaratkan juga ketika melakukan transaksi elektronik hendaknya para pelaku memperhatikan prinsip kehati-hatian, transparansi, akuntabilitas dan kewajaran. Terkait masalah kehati-hatian, transparansi, akuntabilitas dan kewajaran, para ulama Madzhab Syafi'i mensyaratkan bahwa jual beli hendaklah barangnya dapat diserahkan. Artinya barang tersebut haruslah ada dan bisa dihitung atau barang yang diperjual belikan tersebut bisa diukur. Selain itu pula pernyataan barang bisa diserahkan berarti barang yang dijual haruslah barang yang bisa diperjual belikan sesuai kewajaran, tidak diperbolehkan misalnya menjual salah satu dari tiang rumah yang ada atau menjual burung yang sedang terbang di angkasa. Sesuai rukun jual beli yang telah disebutkan di atas, transaksi jual beli dalam Madzhab 
Asy-Syafi'i terjadi ketika 3 (tiga) rukun tersebut ada, maka perbuatan jual beli tersebut terikat dalam akad jual beli. Hal ini berkesesuaian dengan peraturan Indonesia yang menyebutkan bahwa transaksi elektronik yang dituangkan ke dalam kontrak elektronik mengikat para pihak. Transaksi elektronik terjadi pada saat penawaran transaksi yang dikirim pengirim telah diterima dan disetujui penerima. Kesepakatan terjadi pada saat penawaran transaksi yang dikirim oleh pengirim telah diterima dan disetujui oleh penerima persetujuan tersebut dinyatakan dalam penerimaan secara elektronik. Dalam Madzhab AsySyafi'i ditegaskan pula bahwa Jual beli terjadi karena ada rasa kerelaan antar penjual dan pembeli.

Jual beli online dengan sangat memberikan kemudahan transaksi, dan efisiensi waktu. Hal ini sejalan dengan Islam yang menghendaki kemaslahatan dan juga bersifat dinamis terhadap ke majuan pengetahuan dan teknologi dan yang terpenting dalam jual beli juga adalah etika jual beli itu sendiri, yaitu i'tikad baik pelaku usaha dan konsumen dalam bertransaksi. Untuk mengetahui relevansi antara jual beli online menurut hukum Islam terhadap UUPK, terdapat dua unsur yang mesti dikaji, yaitu perilaku pelaku usaha dalam transaksi jual beli online, dimana pelaku usaha harus memberikan informasi yang benar, jelas, dan jujur terkait barang dan/atau jasa yang dijualnya sesuai dengan iklan yang dipaparkan melalui media internet. Yang kedua adalah terkait dengan hak- hak konsumen, yaitu dimana konsumen berhak memperoleh informasi yang benar, jelas, dan jujur mengenai barang dan/atau jasa yang dijual oleh pelaku usaha. Dalam transaksi jual beli online, yang menjadi perhatian juga tidak lepas daripada objek yang ditransaksikan. Dalam hal objek jual beli, Islam telah melarang penjual atau pelaku usaha menjual barang atau jasa yang bertentangan dengan syariah, seperti jual beli khamar, babi, bangkai, dan sebagainya. Islam sangat menekankan agar berbisnis dengan i'tikad yang baik seperti yang telah dicontohkan oleh Rasulullah SAW.

UUPK (Undang-Undang Perlindungan Konsumen) telah menekankan asas keseimbangan antara pelaku usaha dengan konsumen, begitu pula dengan hukum Islam. Asas keseimbangan ini dimaksudkan untuk memberikan keseimbangan antara pelaku usaha dan konsumen, namun dalam transaksi jual beli online, seringkali terjadi pelanggaran yang dilakukan oleh pelaku usaha, seperti adanya 
informasi yang tidak jelas mengenai produk atau barang yang dijual oleh pelaku usaha, baik jual beli secara langsung maupun melalui online. Sehingga konsumen merasa dirugikan karena barang yang dibeli tidak sesuai dengan yang diiklankan melalui media cetak maupun elektronik. Hal ini tentunya melanggar asas keseimbangan yang tercantum dalam UUPK terlebih lagi oleh hukum Islam. (Nusia Nisrina, Disa. 2015:34)

Khususnya di Pondok Pesantren Darussalam Blokagung para santri yang menimba ilmu di pondok sudah mulai banyak yang melakukan transaksi jual beli online tidak hanya santri saja pengurus dan dewan pengasuh pun banyak yang melakukan transaksi tersebut, karena dalam transaksi jual beli online tersebut memiliki kelebihan tersendiri pelaku hanya duduk manis didepan layar tidak usah pergi jauh-jauh tinggal nunggu beberapa hari barang sudah datang. Dalam pembahasan ini peneliti lebih fokus terhadap pembelian kitab dengan sistem online yang dilakukan oleh santri ketika membeli kitab, karena dalam praktiknya mereka masih belum jelas akad apa yang digunakan dalam transaksinya dan bagaimana pendapat fikih muamalah dalam menanggapi transaksi tersebut, karena sudah kita ketahui bahwasanya dalam jual beli ada ketentuan-ketentuanya yang diatur oleh syariat jika ketentuan tersebut tidak terpenuhi apakah jual beli tersebut tetap sah atau tidak dan bagi pelakunya apakah mendapat dosa atau tidak. Dari paparan tersebut peneliti tertarik untuk melakukan penelitian mengenai mekanisme akad transaksi jual beli kitab dengan sistem online yang dilakukan oleh salah satu santri Pondok Pesantren Darussalam Blokagung dan bagaimana pandangan fikih muamalah terhadap transaksi jual beli online. Dari latar belakang di atas rumusan masalahnya adalah: Bagaimana analisis jual beli kitab dengan sistem online menurut perspektif fikih muamalah pada santri di Pondok Pesantren Darussalam Blokagung?

\section{B. KAJIAN TEORI}

\section{Teori Jual Beli}

Jual beli atau bai' secara bahasa adalah saling tukar menukar barang sedangkan secara syara' adalah penjual memberikan kepemilikan sepenuhnya berupa harta kepada pembeli kemudian pembeli memberikan imbalan yang sepadan atas harta tersebut, atau memberikan kepemilikan berupa manfaat yang di legalkan oleh 
syara', apabila pembeli tidak memberikan imbalan maka bukan dinamakan bai' karena dalam akad bai' harus ada unsur mu'awadhah yaitu saling serah terima harta antara penjual dan pembeli, dan apabila yang diserahkan itu yang satu berupa harta dan yang satu bukan harta maka juga tidak bisa dinamakan bai' dan pemberian kepemilikan tersebut juga harus sepenuhnya selama-lamanya, jika tidak maka juga tidak bisa dinamakan jual beli, seperti sewa dalam akad sewa diantara dua orang yang melakukan transaksi memang saling memberikan kepemilikan harta akan tetapi tidak sepenuhnya selama-lamanya. (Syekh Nawawi Al-Bantani, Tausyikh:152).

Setiap manusia pasti akan berusaha untuk memperbaiki dirinya, jika dalam usahanya tersebut manusia menjual dunianya untuk membeli kepentingan akhirat maka ia akan memerdekakan dirinya dari siksa Allah SWT, akan tetapi jika manusia membelinya dengan akhirat maka ia akan menerima siksa dari Allah SWT. (Bajury, Ibrahim, Al- Bajury:339).

Melihat dari penjelasan di atas pengertian bai' adalah penjual menyerahkan harta kepada pembeli, kemudian pembeli memberikan imbalan yang sepadan atas harta tersebut, dengan ketetentuan-ketentuan yang berlaku dalam konteks fikih, seperti ketentuannya penjual, pembeli, barangnya dan akad yang digunakan dalam transaksi jual beli, karena dalam fikih mulai akad sampai baranya ada ketentuanketentuanya sendiri, misalnya penjualnya harus mempunyai hak untuk mentasarufkan hartanya, begitu juga dengan pembeli harus memiliki hak tasaruf, kemudian hartanya untuk diperjual belikan harus berupa harta yang dilegalkan oleh syara', dan masih banyak lainya yang akan diterangkan di pembahasan berikutnya.

\section{Teori Jual Beli Fi-Adzimah}

Al-bai' Fi-Adzimah adalah transaksi jual beli melaluai mekanisme pemesanan, yang mana pembeli harus mensifati benda yang akan dibeli, Al-bai' Fi-Adzimah juga dinamakan salam akan tetapi bedanya jika akad salam harus menyerahkan uang muka di tempat jika $A l$-bai' Fi-Adzimah tidak harus menyerahkan uang muka di tempat (Bajury, Ibrahim, Al- Bajury:339).

\section{Penelitian Terdahulu yang Relevan}

Nurul Atira dengan judul “Jual Beli Online Yang Aman Dan Syar'i”. Penelitian ini secara garis besar membahas tentang praktek-praktek jual beli online yang aman 
dan sesuai syariat. Berikut adalah Jual beli online yang aman dan syari'i menurut pandangan pelaku bisnis online di kalangan mahasiswa Fakultas Syariah dan Hukum UIN Alauddin Makassar. Hasil penelitian menyimpulkan bahwa Jual beli online yang mengandung kemaslahatan dan efisiensi waktu termasuk aspek muamalah yang pada dasarnya diperbolehkan (mubah). Persamaan dengan penelitian ini adalah jenis penelitian merupakan penelitian kualitatif dan teknik pengumpulan data dilakukan dengan cara wawancara, observasi dan dokumentasi. Sedangkan perbedaannya terletak pada landasan teori, objek penelitian, waktu dan tempat penelitian (Atira, Nurul. 2017).

Yusuf Kurniawan dengan judul "Pandangan Hukum Islam Terhadap Praktek Jual Beli Online Dengan Sistem Lelang”. Secara garis besar penelitian ini membahas tentang pandangan hukum Islam terhadap praktek jual beli online dengan sistem lelang. Kasus ini terjadi pada jual beli batu mulia melalui jejaring sosial yang dilakukan oleh mahasiswa Fakultas Syariah Institut Agama Islam Negeri (IAIN) Surakarta Hasil penelitian menyimpulkan bahwa praktik jual beli batu permata dengan sistem lelang di Facebook telah memenuhi penjualan dan pembelian pilar hukum bisnis syariah. Masalah-masalah yang muncul dalam pelelangan di Facebook adalah praktik kekuatan gharar dan najasy, seperti dalam menjual barang yang jelas, penawaran dan berlari, dan hanggling atas harga untuk mengimbangi harga. Untuk menghindari itu praktiknya, setiap pembeli harus melihat ke dalam akun, apakah mereka dipercaya atau tidak dan panjang keberadaan mereka. Persamaan dengan penelitian ini adalah menggunakan metode penelitian kualitatif menggunakan teknik wawancara, observasi, dan dokumentasi, sedangkan perbedaannya adalah landasan teori, objek penelitian dan tempat penelitian (Kurniawan, Yusuf. 2017).

\section{METODE PENELITIAN}

\section{Jenis Penelitian}

Jenis penelitian yang digunakan oleh penulis dalam melakukan penelitian ini adalah penelitian kualitatif yang berbentuk penelitian lapangan (field resarch).

\section{Lokasi dan Waktu Penelitian}

Penelitian ini dilakukan di Pondok Pesantren Darussalam Blokagung, Pondok yang berdiri pada 15 Janurai 1951 oleh Almaghfurlah KH. Mukhtar Syafaat Abdul 
Ghafur, beliu lahir di Kediri 6 maret 1919 dari pasangan suami- isteri KH. Abdul Ghafur dan Nyai Sangkep. Waktu pelaksanaannya di laksanakan pada tanggal 27 Maret 2019 sampai dengan 5 April 2019.

\section{Sumber Data}

Data primer inti yang diperoleh peneliti dalam penelitian ini data yang diperoleh yaitu melalui observasi dan wawancara langsung kepada salah satu santri Pondok Pesantren Darussalam Blokagung yang melakukan transaksi jual beli online. Kemudian data sekunder yang diperoleh yaitu data yang sifatnya pendukung, dalam pembahasan ini data pendukung yang diperoleh oleh peneliti yaitu berupa ayat-ayat Al Qur'an, Hadist dan Kitab.

\section{Teknik Pengumpulan Data}

Pada penelitian ini, peneliti menggunakan teknik pengumpulan data dengan teknik wawancara mendalam, observasi, dan dokumentasi. Dokumentasi dan pengumpulan data pendukung dalam penelitian ini digunakan untuk melengkapi penelitian dan untuk memaksimalkan hasil penelitian. 1) Wawancara, dalam penelitian ini peneliti melakukan wawancara dengan salah satu santri Pondok Pesantren Darussalam Blokagung yang melakukan transaksi jual beli online. 2) Observasi, dalam penelitian ini peneliti mengobservasi kegiatan transaksi jual beli online yang dilakukan oleh salah satu santri Pondok Pesantren Darussalam Blokagung, 3) Dokumentasi, dalam penelitian ini dokumen yang diperoleh peneliti yaitu berupa foto saat berwawancara dengan salah satu santri Pondok Pesantren Darussalam Blokagung yang melakukan transaksi jual beli online.

\section{Alat Analisis Data}

Analisis data dalam penelitian kualitatif terdiri dari tiga kompenen pokok, yaitu reduksi data, penyajian data dan penarikan kesimpulan serta verifikasinya, dalam menganalisis data diperoleh dari catatan lapangan, foto, dokumen berupa laporan, biografi, artikel dan sebagainya. 1) Reduksi Data, peneliti menggunakan reduksi data sebagai bentuk analisis yang menajamkan, menggolongkan, mengarahkan, membuang yang tidak perlu, memudahkan, memahamkan dan mengorganisasi data sedemikian rupa sehingga kesimpulan akhir dapat diambil, 2) Penyajian Data, di mana peneliti melakukan kegiatan menyusun seluruh informasi yang telah didapat setelah melakukan reduksi data, sehingga memudahkan peneliti untuk melakukan 
penarikan kesimpulan, 3) Penarikan Kesimpulan, dalam tahap penarikan kesimpulan berdasarkan berbagai hal yang mendasar tentang persepektif fikih muamalah terhadap jual beli online yang dilakukan salah satu santri Pondok Pesantren Darussalam Bloakgung ketika membeli kitab yang mereka butuhkan.

\section{HASIL PENELITIAN DAN PEMBAHASAN}

Pondok Pesantren Darussalam Blokagung adalah pondok yang didirikan oleh Almarhum Almaghfurlah KH. Mukhtar Syafa'at Abdul Ghoful beliau lahir di Dusun Sumontoro, Desa Ploso Lor, Kecamatan Ploso Wetan, Kabupaten Kediri, pada tanggal 06 Maret 1919. Ia adalah putra keempat dari pasangan suami-isteri KH Abdul Ghafur dan Nyai Sangkep. Kalau dilihat dari silsilah keturunan, KH Mukhtar Syafa'at merupakan salah seorang keturunan pejuang dan ulama, dari silsilah ayahnya, KH Mukhtar Syafa'at putra dari Syafa'at bin Kyai Sobar Iman bin Sultan Diponegoro III (keturunan prajurit Pangeran Diponegoro) dan garis ibu, yaitu Nyai Sangkep binti Kyai Abdurrohman bin Kyai Abdullah (keturunan prajurit Untung Suropati). Beliau wafat pada hari Jumat malam Sabtu, bertepatan pada tanggaal 1 Februari 1991 (17 Rajab $1411 \mathrm{H}$ ) beliau wafat dengan meninggalkan 14 anak (10 putra, 4 putri) dari perkawinannya dengan Nyai Siti Maryam dan 7 anak (4 putra, 3 putri) dari perkawinannya dengan Nyai Hj Musyarofah. Jenazah setelah disemayamkan di rumah duka dan dishalati oleh mu'adzin sampai 17 kali kemudian dimakamkan komplek makam keluarga, sekitar 100 meter arah utara dari Pesantren Darussalam, Blokagung, Banyuwangi.

Sekarang Pondok Pesantren Darussalam Blokagung telah berkembang pesat, sekitar 5000 lebih santri yang mendalami ilmu agama, santri yang mendalami ilmu di pesantren ini berasal Sabang sampai Merauke, bahkan ada yang dari negara lain seperti Thailand. KH. Ahmad Hisyam Syafa'at adalah pengasuh Pondok Pesantren Darussalam Blokagung saat ini, beliau adalah putra pertama dari Almaghfurllah KH. Mukhtar Syafa'at Abdul Ghofur. Dalam memimpin Pondok beliau dibantu oleh adik-adiknya.

Pondok Pesantren Darussalam Blokagung merupakan Pondok Pesantren yang memiliki pendidikan formal yang sangat lengkap mulai dari PAUD, TK, SD, SLTP, SLTA, Perguruan Tinggi ada semua di sini. Ditingkat SLTP Yayasan Pondok Pesantren Darussalam Blokagung memiliki 2 Unit pendidikan yaitu SMP Plus 
Darussalam dan MTs Al Amiriyyah, ditimgkat SLTA Yayasan Pondok Pesantren Darussalam Blokagung memiliki 3 Unit pendidikan yaitu SMA Darussalam, SMK Darussalam dan MA Al Amiriyyah, ditingkat perguruan tinggi Yayasan Pondok Pesantren Darussalam Blokagung memiliki 2 Unit Perguruan Tinggi yaitu Institut Agama Islam Darussalam (IAIDA) da Ma'had Aly Darussalam bahkan pada tahun 2019 Yayasan Pondok Pesantren Darussalam Blokagung sudah memliki Perguruan Tinggi Akademik Komunitas (AK) berbasis Pesantren yang diresmikan langsung oleh Menteri Riset, Teknologi, dan Pendidikan Tinggi Indonesia Prof. Dr. Muhammad Nasir.

Jual beli merupakan suatu kegiatan yang tidak lepas dalam keseharian kita, karena jual beli sendiri, itu merupakan aktifitas atau muamalah yang sifatnya duniawi, karena kita ini masih hidup di dunia maka kita tidak akan terlepas dari yang namanya jual beli, akan tetapi dari sisi lain jual beli merupakan salah satu aktifitas duniawi yang bisa mempengaruhi kehidupan kita di akhirat, jika kita bisa melakukanya dengan sesuai syariat Islam maka insyaAllah kita bisa hidup bahagia di akhirat, Nabi Muhammad SAW Bersabda:

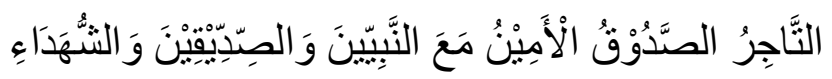

Artinya: "Seorang pedagang muslim yang jujur dan amanah (terpercaya) akan (dikumpulkan) bersama para Nabi, orang-orang shiddiq dan orang-orang yang mati syahid pada hari kiamat (nanti)."

Allah SWT juga berfirman dalam Al Qur'an:

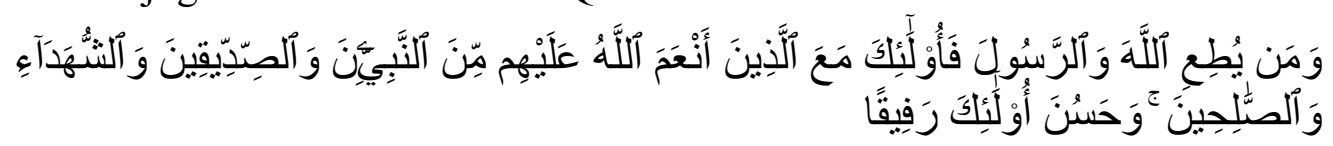

Artinya: "Dan barangsiapa yang mentaati Allah dan Rasul(Nya), mereka itu akan bersama-sama dengan orang-orang yang dianugerahi nikmat oleh Allah, yaitu: Nabi-nabi, para shiddiiqiin, orang-orang yang mati syahid, dan orang-orang saleh. Dan mereka itulah teman yang sebaik-baiknya. (An Nisa': 69)

Dari dalil tersebut menjelaskan betapa mulianya seorang pedagang disisi Allah jika ia memang betul-betul dapat dipercaya. Akan tetapi jika kita melakukanya dengan tidak sesuai syariat Islam bahkan bertolak belakang dengan syarita Islam maka itulah yang akan menjadi faktor penyebab kita hidup binasa di akhirat (Abu Bakar Ustman Muhammad Syattha Dhimyathi, 'Ianatu At-Thalibin:2). 
Nabi Muhammad SAW juga bersabda:

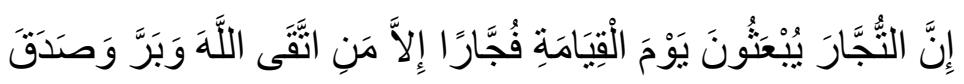

Artinya: "Sesungguhnya para pedagang akan dibangkitkan pada hari kiamat nanti sebagai orang-orang fajir (jahat) kecuali pedagang yang bertakwa pada Allah, berbuat baik dan berlaku jujur" (HR. Tirmidzi dan Ibnu Majah).

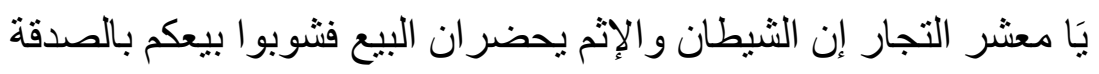

Artinya: "Wahai para pedagang, sesungguhnya setan dan dosa hadir dalam jualbeli. Maka iringilah jual-belimu dengan banyak bersedekah” (HR. Tirmidzi).

Jual beli di zaman modern semakin berkembang dan semaikin banyak macamnya dan juga semakin banyak benda yang diperjual belikan bahkan ada benda yang tidak dilegalkan oleh syariat itupun sekarang banyak yang diperjual belikan seperti arak dan jual beli yang mengandung gharar, sekarang yang lagi marak-maraknya yaitu transaksi jual beli online, khususnya di Pondok Pesantren Darussalam Blokagung para santri yang menimba ilmu di Pondok sudah mulai banyak yang melakukan transaksi jual beli online tidak hanya santri saja pengurus dan dewan pengasuh pun banyak yang melakukan transaksi tersebut, karena dalam transaksi jual beli online tersebut memiliki kelebihan tersendiri pelaku hanya duduk manis didepan layar tidak usah pergi jauh-jauh tinggal nunggu beberapa hari barang sudah datang.

Transaksi jual beli kitab dengan sistem online merupakan salah satu transaksi online yang dilakukan oleh salah satu santri Pondok Pesantren Darussalam Blokagung, mekanisme transaksinya yaitu pertama pembeli melakukan pengamatan untuk mencari penjual yang sesuai dengan keinginan pembeli, kemudian setelah pembeli menemukan penjual yang sesuai kriteria yang diinginkan, lalu ia mulai berkomunikasi melalui telefon sambil bertanya-tanya tentang kitab apa saja yang tersedia di toko milik penjual tersebut, setelah pembeli mulai menemukan kriteria-kriteria yang diinginkan lalu pembeli mulai melakukan perjanjian atau transaksi, dalam transaksi tersebut membuahkan hasil kesepakatan yakni si pembeli bersedia untuk membeli kitab yang telah disebutkan ciri-cirinya. Untuk sistem pembayaranya pembeli membayarkan uang tersebut melalui ATM, akan tetapi pembeli hanya mebayar setengah harga dari harga keseluruhanya 
sampai barang berada di tangan pembeli, setelah barang sudah sampai lalu pembeli melunasi semua pembayarannya. Transaksi tersebut dalam liniatur fikih sama sekali tidak bertentangan dengan hukum fikih, karena dalam praktiknya mulai dari akad, objek transaksi, sampai kedua pelaku transaksi sama sekali tidak melanggar aturan syariah.

Berdasarkan hasil penelitian dilapangan jual beli kitab dengan sistem online pertama kali yang perlu dianalisis adalah bagaimana akad jual beli kitab dengan sistem online tersebut diterapkan. Secara bahasa, akad atau perjanjian itu digunakan untuk banyak arti, yang keseluruhanya kembali pada bentuk ikatan atau penghubungan terhadap dua hal. Sementara akad menurut istilah adalah keterikatan keinginan diri dengan sesuatu yang lain dengan cara memunculkan adanya komitmen tertentu yang disyariatkan (Bajury, Ibrahim. Al-Bajury:336).

Allah SWT berfirman:

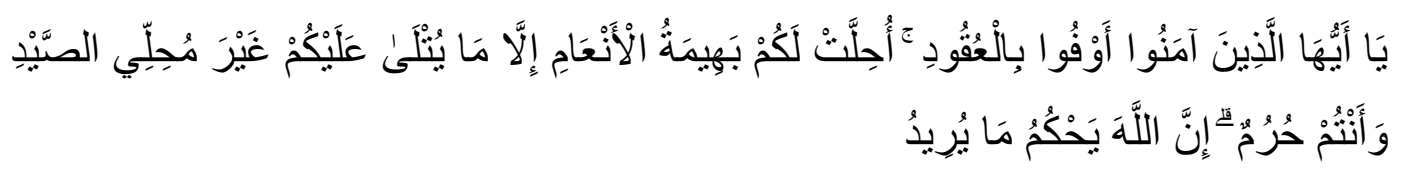

Artinya: "Hai orang-orang yang beriman, penuhilah aqad-aqad itu. Dihalalkan bagimu binatang ternak, kecuali yang akan dibacakan kepadamu. (Yang demikian itu) dengan tidak menghalalkan berburu ketika kamu sedang mengerjakan haji. Sesungguhnya Allah menetapkan hukum-hukum menurut yang dikehendaki-Nya" (Al Maidah: 1).

Akad di sini ada dua yaitu ijab dan qabul contoh ada seorang penjual berkata kepada pembeli "Benda ini aku jual kepadamu dengan harga sepuluh ribu rupiah", kemudian si pemebli mengatakan "Iya barang ini saya beli dengan harga tersebut" ucapan si penjual dinamakan ijab sedangkan ucapan si pembeli dinamakan qabul. Akad merupakan salah satu rukun akad jual beli, apa bila jual beli tidak menggunakan akad maka transaksi jual belinya tidak sah, atau biasa disebut dengan bai' mu'athoh, akan tetapi jika benda yang diperjual belikan bukan benda yang berharga atau benda yang sifatnya remeh maka menggunakan bai' mu'athoh transaksi diperbolehkan. (Al-Kaf, A.M, 2013:15). Kalau dalam kitab yang lainya definisi ijab yaitu suatu perkataan yang memiliki arti penerimaan barang secara jelas (shorih), sedangkan qabul yaitu suatu perkataan yang memiliki arti penyerahan barang sepenuhnya kepada pembeli secara jelas (shorih) (Muhammad Syattha Dhimyathy, Dkk., 2001:3). 
Definisi di atas menjelaskan bahwasannya akad merupakan pertemuan ijab dan qabul yang berakibat timbulnya hukum. Dalam transaksi yang dilakukan oleh santri dalam melakukan transaksi jual beli menurut penulis sudah sesuai dengan pengertian diatas. Pihak yang bertransaksi dalam hal jual beli mereka adalah penjual dan pembeli. Ulama' fikih memberikan beberapa persyaratan dalam hal mengenai kriteria pembeli dan penjual diantaranya yaitu:

Pertama, harus memiliki hak untuk mentasarufkan hartanya, yaitu harus sudah baligh, berakal, tidak tercegah tasarufnya dan pintar. Maka transaksinya orang gila, anak kecil, orang tercegah tasarufnya dan orang yang tidak bisa membelanjakan hartanya dengan semestinya akad jual belinya tidak sah. Yang dimaksud dengan pintar disini yaitu seseorang bisa menggunakan hartanya kepada sesuatu yang memberikan manfaat baginya. Akan tetapi jika tidak bisa menggunakan hartanya kepada sesuatu yang memberikan manfaat baginya seperti membelanjakan hartanya untuk membeli minuman keras maka transaksinya tidak sah (Al-Kaf, A.M. 2013:12).

Kedua, ketentuan yang selanjutnya yaitu penjual maupun pembeli melakukan transaksi tanpa ada paksaan yang tidak semestinya, jika ada unsur paksaan maka transaksinya tidak sah. Akan tetapi jika paksaanya tersebut paksaan yang semestinya diberikan kepada penjual atau pembeli seperti hakim memaksa seseorang untuk menjual hartanya untuk membayar hutang yang telah jatuh tempo, maka transaksinya sah (Al-Kaf, A.M. 2013:12).

Allah SWT Berfirman:

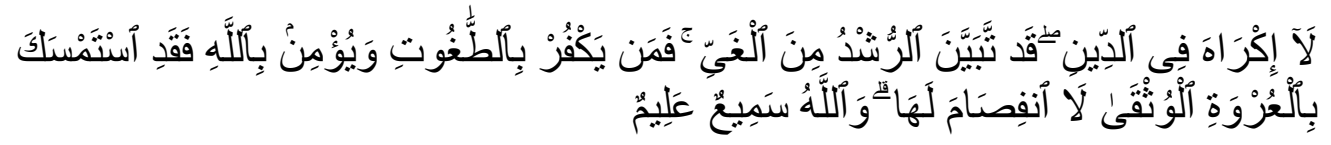

Artinya: "Tidak ada paksaan untuk (memasuki) agama (Islam); sesungguhnya telah jelas jalan yang benar daripada jalan yang sesat. Karena itu barangsiapa yang ingkar kepada Thaghut dan beriman kepada Allah, maka sesungguhnya ia telah berpegang kepada buhul tali yang amat kuat yang tidak akan putus. Dan Allah Maha Mendengar lagi Maha Mengetahui" (Surat Al-Baqoroh:256).

Ketiga, ketentuan yang berikutnya yaitu pembeli atau penjual harus beragama islam jika benda yang diperdagangkan berupa Mushaf Al-Qur'an (Al-Kaf, A.M. 2013:13). 
Keempat, kemudian ketentuan yang terakhir yaitu tidak boleh menjual barang yang sifatnya 'ianah 'ala al-ma'shiat yaitu barang yang sifatnya bisa membantu dalam hal kemaksiatan seperti menjual peralatan yang bisa membantu orang kafir untuk memerangi orang Islam. Adapun bagi orang yang tidak bisa melihat maka transaksinya harus diwakilkan kepada orang lain yang matanya normal. (Al-Kaf, A.M. 2013:12). Allah SWT Berfirman:

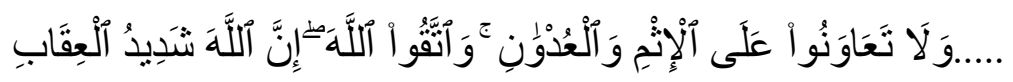

Artinya: “...Dan jangan tolong-menolong dalam berbuat dosa dan pelanggaran. Dan bertakwalah kamu kepada Allah, sesungguhnya Allah amat berat siksa-Nya " (QS. Al Maidah:2).

Ayat ini menunjukkan bahwa terlarang saling tolong menolong dalam maksiat atau dosa. Berdasarkan pengamatan yang dilakukan oleh penulis ketika melakukan penelitian dari beberapa ketentuan di atas penjual dan pembeli sudah memenuhi ketentuan-ketentuan tersebut akan tetapi hendaknya dari pihak penjual mencamtumkan beberapa ketentuan yang mungkin sangat diperlukan misalnya sudah baligh, berakal, tidak tercegah tasarufnya dan pintar, dikalangan masyarakat umum ketentuan tersebut jelas masih banyak yang belum mengetahuinya, karena yang dinamakan orang yang tercegah tasarufnya ini masih sangat lebar sekali penjelasanya mungkin hanya orang yang pernah mencari di Pondok Pesantren saja yang mengetahui tentang ini.

Objek transaksi yang telah diteliti oleh penulis yaitu berupa kitab, khususnya kitab-kitab yang sangat dibutuhkan oleh santri Pondok Pesantren Darussalam Blokagung Banyuwangi. Dalam dalam konteks fikih ada beberapa ketentuan barang yang dilegalkan untuk diperjual-belikan diantaranya yaitu:

1. Harta yang diperjual-belikan harus suci dzatnya, maka tidak boleh menjual benda yang najis dzatnya, jika yang najis bukan dzatnya dan mungkin untuk disucikan maka boleh untuk dijual. (Al-Kaf, A.M, 2013:14) Dalam hadist disebutkan:

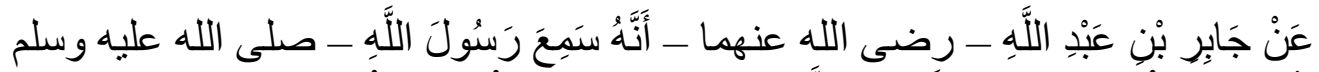

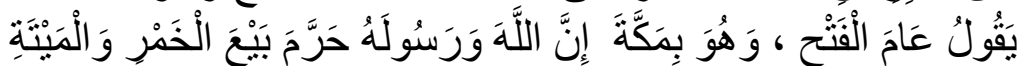

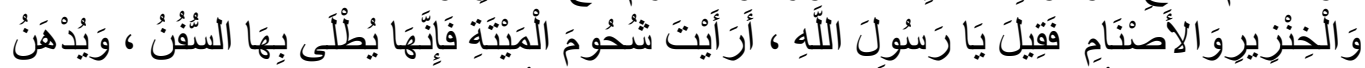

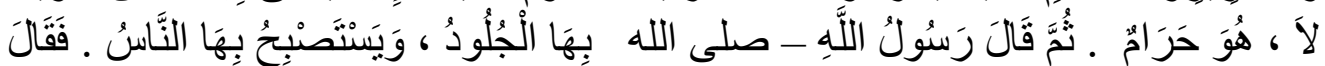

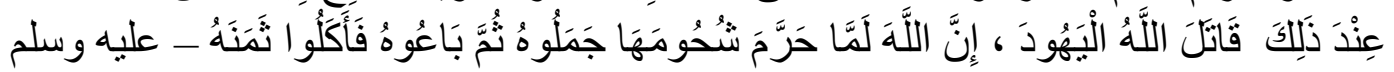


Artinya: "Dari Jabir bin Abdillah, beliau mendengar Rasulullah shallallahu 'alaihi wa sallam bersabda di Mekah saat penaklukan kota Mekah. Sesungguhnya, Allah dan Rasul-Nya mengharamkan jual beli khamar, bangkai, babi, dan patung." Ada yang bertanya, "Wahai Rasulullah, apa pendapatmu mengenai jual beli lemak bangkai, mengingat lemak bangkai itu dipakai untuk menambal perahu, meminyaki kulit, dan dijadikan minyak untuk penerangan?" Nabi shallallahu 'alaihi wa sallam bersabda, "Tidak boleh! Jual beli lemak bangkai itu haram." Kemudian, Rasulullah shallallahu 'alaihi wa sallam bersabda, "Semoga Allah melaknat Yahudi. Sesungguhnya, tatkala Allah mengharamkan lemak bangkai, mereka mencairkannya lalu menjual minyak dari lemak bangkai tersebut, kemudian mereka memakan hasil penjualannya” (HR. Bukhari no. 2236 dan Muslim, no. 4132).

2. Harta yang diperjual-belikan harus memiliki manfaat, maka tidak boleh menjual benda yang tidak ada manfaatnya seperti semut. (Al-Kaf, A.M., 2013:14)

3. Harta yang diperjual-belikan harus bisa diserahkan ketika akad, maka menjual benda yang tidak bisa diserahkan ketika akad transaksinya tidak sah, seperti menjual burung yang beterbangan di udara. (Al-Kaf, A.M., 2013:14)

4. Harta yang diperjual-belikan harus harus miliknya sendiri, maka menjual benda, yang bukan haknya tidak diperbolehkan seperti yang disabdakan oleh Nabi:

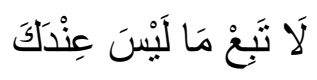

Arinya: "Tidak boleh menjual harta yang bukan haknya” (Al-Kaf, A.M., 2013:15).

5. Harta yang diperjual-belikan harus harus diketahui bentuknya secara jelas, misalnya menjual benda yang tidak ada pada saat transaksi berlangsung, apabila sebelum transaksi sipembeli sudah melihat bentuk benda tersebut dengan jelas dan dan benda tersebut merupakan benda yang tidak mudah berubah bentuk maka ada yang mengatakan diperbolehkan (Al-Kaf, A.M., 2013:15). Nabi Muhammad SAW Bersabda:

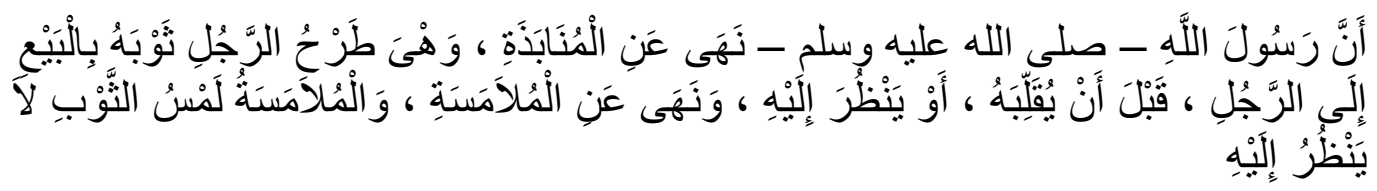

Artinya: "Rasulullah shallallahu 'alaihi wa sallam melarang dari munabadzah, yaitu seseorang melempar pakaiannya kepada yang lain dan itulah yang dibeli tanpa dibolak-balik terlebih dahulu atau tanpa dilihat keadaan pakaiannya. Begitu pula beliau melarang dari mulamasah, yaitu pakaian 
yang disentuh itulah yang dibeli tanpa melihat keadaaannya" (HR. Bukhari no. 2144).

Dari ketentuan-ketentuan di atas objek akad yang diteliti oleh penulis sudah memenuhinya. Berdasarkan penelitian yang dilakukan oleh penulis pembayaran yang diterapkan oleh penjual dan pembeli yaitu melalui ATM, dalam proses pembayaranya pembeli tidak langsung membayarkan semua harga kitab yang dibeli, melainkan dibayarkan setengah dahulu kemudian ketika barang sudah sampai ditangan pembeli baru uang dibayarkan seluruhnya. Kemudian dalam proses pengiriman barangnya biasanya penjual mengirimkan barang melalui jasa pengiriman barang JNE, untuk biaya pengiriman sudah ditanggung oleh penjual.

Transaksi jual beli kitab dengan sistem online yang dilakukan oleh santri Pondok Pesantren Darussalam Blokagung sesuai dengan penelitian yang dilakukan oleh penulis sudah sesuai dengan ketentuan syariat yang telah di sebutkan di atas, karena dalam bertransaksi hal yang dibutuhkan adalah adanya ijab dan qabul. Dalam bertransaksi juga dalam kitab Fiqh As-Sunnah dijelaskan bahwasanya boleh bertransaksi melalui tulisan tidak harus melalui ucapan. (Sayyid Sabiq, 2011:148). Dan dalam bertransaksi juga, dalam kitab Bujaerami 'Ala Al-Khatib karya Syekh Khatib Syarbini diterangkan tidak harus melakukan pembayaran ketika melakukan perjanjian, jadi boleh melakukan perjanjian terlebih dahulu kemudian menyebutkan kriteria kitab yang dibeli baru ketika kitab sudah datang uang akan ditransver melalui ATM terdekat, atau melalui BRI Link atau yang lainya. Penjual dan pembeli menurut penulis sesuai dengan penelitian yang telah dilakukan juga sudah sesuai dengan ketentuan syariat, dari beberapa syarat mulai dari baligh, berakal dan yang lainya keseluruhan tersebut sesui dengan ketentuan syariat. Objek transaksinya pun sesuai dengan ketetentuan di atas.

\section{E. KESIMPULAN}

Transaksi jual beli merupakan transaksi yang mana penjual dan pembeli melakukan kesepakatan saling memberikan kepemilikan sepenuhnya berupa harta kepada pembeli kemudian pembeli memberikan imbalan yang sepadan atas harta tersebut, atau memberikan kepemilikan berupa manfaat yang di legalkan oleh syara', apabila pembeli tidak memberikan imbalan maka bukan dinamakan bai' karena dalam akad bai' harus ada unsur mu'awadhah yaitu saling serah terima harta 
antara penjual dan pembeli, dan apabila yang diserahkan itu yang satu berupa harta dan yang satu bukan harta maka juga tidak bisa dinamakan bai' dan pemberian kepemilikan tersebut juga harus sepenuhnya selama-lamanya, jika tidak maka juga tidak bisa dinamakan jual beli, seperti sewa dalam akad sewa diantara dua orang yang melakukan transaksi memang saling memberikan kepemilikan harta akan tetapi tidak sepenuhnya selama-lamanya. (Syekh Nawawi Al-Bantanil, Tausyikh:152). Menurut Syekh Khotib di dalam kitab AL- Bajury diterangkan jual beli adalah saling tukar-menukar harta dengan syarat- syarat tertentu.

Sedangkan transaksi jual beli online merupakan transaksi yang sama dengan keterangan di atas akan tetapi dilakukan malalui via media sosial. mekanisme transaksinya yaitu pertama pembeli melakukan pengamatan untuk mencari penjual yang sesuai dengan keinginan pembeli, kemudian setelah pembeli menemukan penjual yang sesuai kriteria yang diinginkan, lalu ia mulai berkomunikasi melalui telefon sambil bertanya-tanya tentang kitab apa saja yang tersedia di toko milik penjual tersebut, setelah pembeli mulai menemukan kriteria- kriteria yang diinginkan lalu pembeli mulai melakukan perjanjian atau transaksi, dalam transaksi tersebut membuahkan hasil kesepakatan yakni si pembeli bersedia untuk membeli kitab yang telah disebutkan ciri-cirinya kemudian pembayaran dilakukan melalui ATM, dalam proses pembayaranya pembeli tidak langsung membayarkan semua harga kitab yang dibeli, melainkan dibayarkan setengah dahulu kemudian ketika barang sudah sampai ditanagan pembeli baru uang dibayarkan seluruhnya. Kemudian dalam proses pengiriman barangnya biasanya penjual mengirimkan barang melalui jasa pengiriman barang JNE, untuk biaya pengiriman sudah ditanggung oleh penjual. Pembayaran dilakukan melalui ATM, dalam proses pembayaranya pembeli tidak langsung membayarkan semua harga kitab yang dibeli, melainkan dibayarkan setengah dahulu kemudian ketika barang sudah sampai ditanagan pembeli baru uang dibayarkan seluruhnya. Kemudian dalam proses pengiriman barangnya biasanya penjual mengirim kan barang melalui jasa pengiriman barang JNE, untuk biaya pengiriman sudah ditanggung oleh penjual. 
Jurnal Ekonomi Syariah Darussalam

Vol I No I Agustus 2020, ISSN: 2745-8407

\section{DAFTAR PUSTAKA}

Al-Kaf, A.M. 2013. Taqriratussadidah Bajury. Ibrahim: Al-Bajury.

Muhammad Syattha Dhimyathy, Abu Bakar Ustman. 2010. 'Ianatu At-Thalibin. Surabaya: Daru Al-Jauhar.

Muh Fitrah, Lutfiyah. 2017. Metode Penelitian Tindakan Kelas dan Studi Kasus Surabaya: Erlangga.

Munir Sukoco, Badri. 2017. Manajemen Administrasi Perkantoran Modern. Surabaya: Erlangga.

Shallah As Shawi Dan Muslih Abdullah. 2012. Fikih Ekonomi Keuangan Islam. Jakarta: Darul Haq.

Syekh Khatib Syarbini. Bujaerami 'Ala Al-Khatib.

Syekh Nawawi Al-Bantani. Tausyikh. 